\title{
Study on Effect of Pectin Based Edible Coating on the Shelf Life of Sapota Fruits
}

\author{
Joslin Menezes and K.A.Athmaselvi \\ Department of Food Process and Engineering, \\ School of Bioengineering, SRM University, Chennai - 603 203, India. \\ http://dx.doi.org/10.13005/bbra/2152
}

(Received: 17 April 2016; accepted: 13 May 2016)

\begin{abstract}
Edible coating is defined as the thin layer of edible components formed on the surface of food materials. It has the similar effects of modified atmospheric packaging which alters the atmosphere surrounding the food products. It is used as a post-harvest technique to retain and improve the quality of the food products such as fruits and vegetables. In the present work the edible coating was prepared using the polysaccharide pectin (3\%), glycerol (2.5\%), polyvinyl alcohol (1.25\%) and citric acid (1\%) and the sapota fruits were coated using the dipping method. The both control and coated fruits were stored at room temperature $\left(30 \pm 3^{\circ} \mathrm{C}\right)$. The physico- chemical parameters were measured in the regular interval of time i.e., $1,3,5,7$ and $11^{\text {th }}$ day of the storage. The pectin coated sapota fruits showed reduced rate of change in weight loss, acidity, TSS, pH, colour, ascorbic acid and the firmness when compared to that of control fruits. The shelf life of coated sapota fruits were extended upto 11 days where as the control fruits were in the edible state upto $6^{\text {th }}$ day at room temperature storage.
\end{abstract}

Keywords: Pectin, edible coating, sapota, physico -chemical parameters, textural properties.

The marketability of the food products such as fresh fruits and vegetables mainly depends upon appearance, flavor, colour, texture and nutritional value and microbial safety. The maintenance of these properties is a challenging $\operatorname{task}^{[1]}$. Different techniques have been used in the preservation of these food products; one such technique is edible packaging including edible coatings and films. The edible films and coatings are the primary packaging which is prepared from edible materials ${ }^{[2]}$. These are used as the preservation technique of agricultural produce and many other food products because of their barrier

\footnotetext{
* To whom all correspondence should be addressed. E-mail: athmaphd@gmail.com
}

properties against the transfer of gas, moisture and solute molecules between the food and the surrounding. These coatings and films can be consumed along with the food product which is considered as their main advantage over the synthetic packaging ${ }^{[3]}$. The concept of application of edible coatings on the agricultural produce is not new. It has been found that in the early $12^{\text {th }}$ century, the fruits like oranges and lemons were coated with wax to retain their quality and extend the shelf life for longer period of time ${ }^{[4]}$. Since then these edible films and coatings have been used on different fruits in order to extend their shelf life.

Sapota (Achras sapota Linn.) is a perishable fruit which has played major role in the traditional Indian medicine because of its various useful properties ${ }^{[3]}$. India is considered to be the largest producer of sapota fruits with annual 
production of 11.17 lakh tones, followed by the countries Mexico, Guatemala and Venezuela. Sapota fruits are the rich source of sugar containing 12 to $14 \%{ }^{[5]}$. It is also a source of chicle gum which is used in the manufacture of chewing gum ${ }^{[6]}$. In addition to these, sapota fruits also contain acids, amino acids, proteins, minerals such as potassium, iron, calcium; phenolic compounds such as catechin, carotenoids, gallic acids, chlorogenic acid, ascorbic acid, leucodelphinidin, leucopelargonidin and leucocyanidin ${ }^{[3]}$.The different food products such as jam, osodehydrated slices, jellies, squash, dries sapota pieces, milk shake, blended sapota drinks, nectar, sweet chutney, pickle, candy and preserve can be produced from the sapota fruits ${ }^{[5]}$.Sapota fruits are highly perishable and there is requirement for the effective preservative method to improve their post harvest life. The edible packaging including edible films and coatings can be used to extend the shelf life of these sapota fruits.

Edible coatings and films are made up of three different components; they are polysaccharides (such as cellulose and its derivatives, pectin, starch, dextrins, alginates and plant gums), proteins (such as soy proteins, milk proteins, collagen, corn zein and albumins) and lipids (such as fatty acids and their esters, mono $\mathrm{di}-$ and triglycerides, beeswax, carnauba etc. $)^{[3][7]}$. These components have their own advantages and disadvantages and their effect on the shelf life extension of fruits depends on the storage conditions ${ }^{[8]}$.Chitosan, pectin derivatives, cellulose, starch, seaweed extracts etc are the most commonly used polysaccharide components in the preparation of edible coating. These polysaccharide based coatings have better mechanical strength but are poor in terms of moisture and gas barrier properties ${ }^{[9]}$.
Pectin is a polysaccharide made up of galactouronic acids and these are considered as amorphous, white coloured colloidal carbohydrate. The fruits such as apples, currants contain the high concentration of pectin in their ripened stage ${ }^{[10]}$. In the food industries the pectin is used as gelling and stabilizing agents ${ }^{[11]}$.These have been used in the preservation of many fruits and vegetable such as guava, apples, avocado, carrot, papaya, tomato etc ${ }^{[10]}$. The strawberries coated with pectin based edible coating showed reduced rate of change in the firmness, weight loss, and also reduced the spoilage of fruits due to microbial infection ${ }^{[12]}$. The combination of pectin coating and the osmotic dehydration has been used in the preservation of fresh cut melons in the refrigerated temperature storage ${ }^{[13]}$. The pectin based edible coating incorporated with oregano essential oil was found to be effective in reducing the fungal decay and also resulted in the increased antioxidant activity of tomatoes ${ }^{[14]}$. The effect of the pectin coating containing green tea extracts was studied on the quality of irradiated pork patty ${ }^{[15]}$.

\section{MATERIALSANDMETHODS}

\section{The preparation of pectin based edible coating solution}

The pectin (3\%) is dissolved in distilled water at the temperature of $90^{\circ} \mathrm{C}$. To this pectin solution, glycerol (2.5\%), polyvinyl alcohol (1.25\%) and citric acid (1\%) is added and mixed using the magnetic stirrer. After mixing, the solution is cooled to room temperature and allowed to degas ${ }^{[12]}$.

\section{Physico chemical analysis of fruits Weight loss}

The weight loss in control and the coated fruit samples is measured using the following formula ${ }^{[16]}$.

Table 1. Weight loss and pHvalues of control and coated sapota fruits

\begin{tabular}{lcccc}
\hline Days & \multicolumn{2}{c}{ Weight Loss (\%) } & \multicolumn{2}{c}{$\mathrm{pH}$} \\
& Control & Coated & Control & Coated \\
\hline 1 & $2.22 \pm 0.5$ & $1.19 \pm 0.1$ & $5.27 \pm 0.05$ & $5.34 \pm 0.01$ \\
3 & $9.836 \pm 0.3$ & $6.786 \pm 0.8$ & $5.67 \pm 0.02$ & $5.45 \pm 0.07$ \\
5 & $16.98 \pm 0.4$ & $10.14 \pm 0.2$ & $5.96 \pm 0.03$ & $5.65 \pm 0.1$ \\
7 & - & $13.69 \pm 0.6$ & - & $5.87 \pm 0.09$ \\
11 & - & $17.28 \pm 0.5$ & - & $5.92 \pm 0.04$ \\
\hline
\end{tabular}


Weight $\operatorname{loss}(\%)=\frac{\text { Initial weight }- \text { final weight }}{\text { initial weight }} * 100$

\section{Total soluble solids (TSS)}

The TSS content of the fruits is determined using the hand refractrometer. A drop of fruit juice is placed onto the plate surface of the refractrometer and the reading is taken directly as ${ }^{\circ}$ Brix $^{[11]}$.

pH

The $\mathrm{pH}$ of the fruit pulp is measured using the digital $\mathrm{pH}$ meter. Initially the $\mathrm{pH}$ meter is calibrated using the $\mathrm{pH} 7$ buffer solution and then the probe of the $\mathrm{pH}$ meter is placed into the fruit juice and reading is taken directly ${ }^{[17]}$.

\section{Titratable acidity}

Acidity is measured by the titration method using $0.1 \mathrm{~N} \mathrm{NaOH}$ solution. The acidity is measured using the following formula ${ }^{[17]}$.

$$
\operatorname{Acidity}(\%)=\frac{\begin{array}{c}
\text { Titre value } * \text { normality of } \mathrm{NaOH} \\
* \text { total volume } * \text { acid factor }
\end{array}}{\text { weight of the sample } *} * 100
$$

Colour

The $\mathrm{L}^{*}, \mathrm{a}^{*}$ and $\mathrm{b}^{*}$ values of the fruit peel is measured during the storage using the Hunter Colourimeter. The $\mathrm{L}^{*}$ values depicts the lightness,

Table 2. Acidity and TSS values of control and coated sapota fruits

\begin{tabular}{lcccc}
\hline \multirow{2}{*}{ Days } & \multicolumn{2}{c}{ Acidity (\%) } & \multicolumn{2}{c}{ TSS(ÚBrix) } \\
& Control & Coated & Control & Coated \\
\hline 1 & $0.405 \pm 0.6$ & $0.426 \pm 0.1$ & $21 \pm 0.00$ & $22 \pm 0.00$ \\
3 & $0.341 \pm 0.2$ & $0.32 \pm 0.3$ & $27 \pm 0.00$ & $23 \pm 0.00$ \\
5 & $0.16 \pm 0.09$ & $0.245 \pm 0.9$ & $29 \pm 0.00$ & $24 \pm 0.00$ \\
7 & - & $0.224 \pm 0.5$ & - & $28 \pm 0.00$ \\
11 & - & $0.18 \pm 0.2$ & - & $31 \pm 0.00$ \\
\hline
\end{tabular}

$a^{*}$ values represent the extent of the redness or greenness and $b^{*}$ values represent the extent of blueness or yellowness ${ }^{[17]}$.

\section{Ascorbic acid}

Ascorbic acid is the acid which is present in the highest amount in the sapota fruits. It is measured by the titration method using 2, 6 dichlorophenol indophenol ${ }^{[17]}$.

$$
\begin{aligned}
& \text { Ascorbic acid } \frac{\mathrm{mg}}{100 \mathrm{~g}} \text { of sample }= \\
& \frac{0.5 \mathrm{mg} * \mathrm{~V} 1 * 100 \mathrm{ml}}{\mathrm{V} 1 * 5 \mathrm{ml} * \text { weight of sample }} * 100
\end{aligned}
$$

Where,

$\mathrm{V}_{1}$ is the titre value of standard ascorbic acid $\mathrm{V}_{2}$ is the titre value of fruit pulp.

\section{Firmness}

The firmness of both control and the coated sapota fruits was measured during the storage period by using the texture analyzer. The penetration test was used to determine the firmness of fruits. A probe of $2 \mathrm{~mm}$ diameter was allowed to penetrate through the fruits upto $10 \mathrm{~mm}$ depth. During the analysis, the load cell of $50 \mathrm{Kg}$, pretest speed $1.5 \mathrm{~mm} / \mathrm{sec}$, test speed $1.0 \mathrm{~mm} / \mathrm{sec}$, post test speed $10 \mathrm{~mm} / \mathrm{sec}$ was maintained. The force that is required to penetrate through the surface of fruits was measured in terms of gram ${ }^{[11]}$.

\section{RESULTS AND DISCUSSION}

The coated and uncoated sapota fruits were stored at room temperature $\left(30 \pm 3^{\circ} \mathrm{C}\right)$. The physico chemical parameters such as weight loss, TSS, titratable acidity, $\mathrm{pH}$, colour, ascorbic acid and firmness of both control and coated sapota

Table 3. Ascorbic acid and firmness values of control and coated sapota fruits

\begin{tabular}{lcccc}
\hline \multirow{2}{*}{ Days } & \multicolumn{2}{c}{ Ascorbic acid (\%) } & \multicolumn{2}{c}{ Firmness (g) } \\
& Control & Coated & Control & Coated \\
\hline 1 & $14.68 \pm 0.5$ & $14.2 \pm 0.13$ & $429.49 \pm 0.3$ & $563.49 \pm 0.42$ \\
3 & $10.73 \pm 0.8$ & $12.64 \pm 0.25$ & $145.779 \pm 0.5$ & $440.658 \pm 0.7$ \\
5 & $6.08 \pm 0.3$ & $10.57 \pm 0.32$ & $79.87 \pm 0.45$ & $227.891 \pm 0.1$ \\
7 & - & $8.14 \pm 0.20$ & - & $187.97 \pm 0.05$ \\
11 & - & $5.91 \pm 0.15$ & - & $75.337 \pm 0.9$ \\
\hline
\end{tabular}


Table 4. $\mathrm{L}^{*}$, $\mathrm{a}^{*}$ and $\mathrm{b}^{*}$ values of control and coated sapota peel

\begin{tabular}{ccccccc}
\hline \multirow{2}{*}{ Days } & \multicolumn{2}{c}{$\mathrm{L}^{*}$ Control } & $\mathrm{a}^{*}$ & \multicolumn{2}{c}{$\mathrm{b}^{*}$} \\
& Control & Coated & Control & Coated \\
\hline $\mathbf{1}$ & $48.2 \pm 0.61$ & $49.27 \pm 0.53$ & $5.77 \pm 0.4$ & $5.24 \pm 0.9$ & $28.62 \pm 0.5$ & $29.65 \pm 0.26$ \\
$\mathbf{3}$ & $43.45 \pm 0.3$ & $47.46 \pm 0.4$ & $8.68 \pm 0.15$ & $6.68 \pm 0.45$ & $22.37 \pm 0.13$ & $27.88 \pm 0.4$ \\
$\mathbf{5}$ & $39.47 \pm 0.11$ & $45.76 \pm 0.2$ & $11.52 \pm 0.34$ & $9.09 \pm 0.24$ & $15.44 \pm 0.31$ & $24.21 \pm 0.38$ \\
$\mathbf{7}$ & - & $41.45 \pm 0.67$ & - & $10.11 \pm 0.3$ & - & $20.56 \pm 0.51$ \\
$\mathbf{1 1}$ & - & $39.32 \pm 0.1$ & - & $11.57 \pm 0.63$ & - & $16.49 \pm 0.64$ \\
\hline
\end{tabular}

fruits were measured during the storage.

\section{Weight loss}

The weight loss of control fruits increased from $2.22 \pm 0.5 \%$ to $16.98 \pm 0.4 \%$ whereas the weight loss in the coated fruits increased from $1.19 \pm 0.1 \%$ to $17.28 \pm 0.5 \%$ as shown in table 1 . It was found that, the sapota fruits coated with $2.5 \%$ corn starch showed the weight loss of $17.56 \%$ on $9^{\text {th }}$ day of storage $e^{[18]}$.

pH

The $\mathrm{pH}$ value of both coated and control sapota fruits decreased during the storage. The $\mathrm{pH}$ value of control fruits ranged from $5.27 \pm 0.05$ to $5.96 \pm 0.03$ and that of coated fruits ranged from $5.34 \pm 0.01$ to $5.92 \pm 0.04$ as shown in table 1 . TSS

The value of TSS increased as the fruits ripened. In the case of control fruits, TSS value increased from $21 \pm 0.00^{\circ}$ Brix to $29 \pm 0.00^{\circ}$ Brix where as in the coated fruits the TSS value increased from $22 \pm 0.00^{\circ}$ Brix to $31 \pm 0.00^{\circ}$ Brix as shown in table 2. In the corn starch (2.5\%) coated sapota fruits TSS was found to be $28.19^{\circ}$ Brix on $9^{\text {th }}$ day of storage $\mathrm{e}^{[18]}$.

\section{Titratable acidity}

The titratable or total acidity of control fruits decreased from $0.405 \pm 0.6 \%$ to $0.16 \pm 0.09 \%$ where as in the coated fruits acidity decreased from $0.426 \pm 0.1 \%$ to $0.18 \pm 0.2 \%$ as shown in table 2 . The sapota fruits coated with $2.5 \%$ corn starch showed the acidity of $0.45 \%$ on $3^{\text {rd }}$ day of storage at ambient conditions $^{[18]}$.

\section{Ascorbic acid}

The ascorbic acid content of control fruits reduced from $14.68 \pm 0.5 \mathrm{mg} / 100 \mathrm{~g}$ of fruit pulp to $6.08 \pm 0.3 \mathrm{mg} / 100 \mathrm{~g}$ of fruit pulp where as in the coated fruits the ascorbic acid decreased from $14.2 \pm 0.13 \mathrm{mg} / 100 \mathrm{~g}$ of fruit pulp to $5.91 \pm 0.15 \mathrm{mg} /$
$100 \mathrm{~g}$ of fruit pulp as shown in table 3. It was reported that, in the sapota fruits coated by corn starch $(2.5 \%)$, the ascorbic acid content was decreased to $9.51 \%$ on the $9^{\text {th }}$ day of storage ${ }^{[18]}$.

\section{Firmnes}

The firmness of both control and coated sapota fruits reduced during the storage period. This reduction was at the higher rate in the control fruits when compared to that of pectin coated fruits. The flesh firmness of control and coated fruits measured on $1,3,5,7$ and $11^{\text {th }}$ day of storage and it ranged from $429.49 \pm 0.3$ to $79.87 \pm 0.45 \mathrm{~g}$ and from $563.49 \pm 0.42$ to $75.337 \pm 0.6$ g respectively as shown in table 3.

\section{Colour measurement}

$L^{*}, a^{*}, b^{*}$ values of sapota peel were measured. $L^{*}$ value of peel decreased as the fruits ripened. In the case of control fruits, $\mathrm{L}^{*}$ value of peel decreased from $48.2 \pm 0.61$ to $39.47 \pm 0.11$ and in the coated fruits, the $\mathrm{L}^{*}$ value decreased from $49.27 \pm 0.53$ to $39.32 \pm 0.1$ as shown in table 4 .

The $\mathrm{a}^{*}$ values of peel of both control and coated fruits increased during the storage. The $\mathrm{a}^{*}$ value of the peel of the control fruits increased from $5.77 \pm 0.4$ to $11.52 \pm 0.34$ and that of coated fruits increased from $5.24 \pm 0.9$ to $11.57 \pm 0.63$ during the storage as shown in table 3.As the fruits ripened during the storage, the $b^{*}$ value of peel of both control and coated fruits decreased. In the case of control fruits, the $b^{*}$ value of peel decreased from $28.62 \pm 0.5$ to $15.44 \pm 0.31$ and that of coated fruits decreased from $29.65 \pm 0.26$ to $16.49 \pm 0.64$ as shown in table 4.

The pectin based edible coating extended the shelf life of sapota fruits upto 11 days by 
delaying the changes in the physico chemical parameters such as weight loss, TSS, $\mathrm{pH}$, total acidity, ascorbic acid, firmness and colour where as the uncoated sapota fruits were in the edible state upto $5^{\text {th }}$ day at room temperature $\left(30 \pm 3^{\circ} \mathrm{C}\right)$.

\section{REFERENCES}

1. Zahra, N., Ebrahim, A., Hassan, S., Reza, A.C. Effect of methylcellulose based edible coating on strawberry's quality maintenance during storage.Journal of Food processing and Preservation, 2014; 39:80-90.

2. Melvin, A.P., Shin,J.L. The application of edible polymeric films and coatings in the food industry. J. Food Process Technol.,2012; 4(2):12.

3. Anand, P.K., Policegaudra, R.S., Aradhya, S. Chemical composition and antioxidant activity of sapota (Achras sapota Linn.) fruit.Journal of Food Biochemistry, 2007; 31(3): 399-414.

4. Olivas, G.I., Davila - Avina, J.E., Salas- Salazar, N.A., Molina, S.J. Use of edible coatings to preserve the quality of fruits and vegetables during storage. International Journal For Reviews In Postharvest Biology And Technology, 2008; 4(3):1-10.

5. Pawar, C.D., Patil, A.A., Joshi,J.D. Physicochemical parameters of sapota fruits at different maturity stages. Karnataka J. Agric. Sci., 2011; 24(3):420 - 421.

6. Alexander, J.M., Nola, G.T. Volatile flavor components of sapodilla fruit (Achras sapota L). J. Agric. Food Chem., 1982; 30(3):515-517.

7. Andrzej, T., Patrycja, W., Aneta,C. Application of composite protective coatings on the surface of sausages with different water content. Acta. Sci. Pol.Technol. Aliment.,2010; 9(2):151-159.

8. Arantzazu, V., Nuria,B., Alfonso, J., Maria,C.G.Natural pectin polysaccharides as edible coatings. Coatings,2015; 5(4): 865-886.

9. Jafarizadeh, M.H., Osman, A., Tan, C.P., Abdul,R.R. Evaluation of effectiveness of three cellulose derivative based edible coatings on changes of physico-chemical characteristics of 'Berangan' banana(Musa sapientum cv.
Berangan) during storage at ambient conditions. International Food Research Journal,2011; 18(4):1381-1386.

10. Mohnen,D. Pectin structure and biosynthesis. Curr. Opin. Plant Biol.,2008; 11(3):266-277.

11. Padmaja, N., Don, Bosco, S. J., Rao, J. S. Physico chemical analysis of sapota (Manilkara Zapota) coated by edible aloe vera gel. Int. J. Appl. Sci. Biotechnol., 2015; 3(1):20-25.

12. Yossef, M.A. Comparison of different edible coatings materials for improvement of quality and shelf life of perishable fruits. Middle East $j$. Appl. Sci., 2014; 4(2):416-424.

13. Cristiane, C.F., Claire, I.G.L., Sandra, M.C.G., Miriam, D.H. Effect of osmotic dehydration and pectin edible coatings on quality and shelf life of fresh-cut melon. Food Bioprocess Technol., 2013; 6(1):80-91.

14. Isela, R.G., Reynaldo, C.V.M., Brenda, A.S.E., Gustavo, A.G.A., Edgar, M., Melissa, G.P.M., Melvin, R.T.R., Luis, A.O.R., Fernando, A.Z.J. Oregano (Lippia graveolens) essential oil added within pectin edible coatings prevents fungal decay and increases the antioxidant capacity of treated tomatoes. Journal of the Science of Food and Technology, 2016; 96:1 -7.

15. Kang, H.J., Jo, C., Kwon, J.H., Kim, J.H., Chung, H.J., Byun, M.W. Effect of a pectinbased edible coating containing green tea powder on the quality of irradiated pork patty. Food Control, 2007; 18(5):430-435.

16. Mir, Muhammad, N.Q., Masood, S.B., Muhammad, A. K., Muhammad, S. , Main, K.S., Muhammad, Y., Muhammad, T.S., Farhan, S. Effects of different coatings on preserving fruit quality of sweet cherries grown in Skardu valley of Gilgit-Baltistan during storage. Int. J. Biosci., 2014; 5(5):24-32.

17. Ranganna, S. Hand book of analysis and quality control for fruits and vegetable products. $3^{\text {rd }} \mathrm{ed}$., Tata Mc GrawHill publishing Co.Ltd, New Delhi, 1999.

18. Dey, K., Ghosh, A., Bhowmick, N., Ghosh, A Physico - chemical properties of sapota (Manilkara achras(Mill) Fosb.)fruits coated with corn starch. J. Crop and Weed, 2014; 10(2):43 - 49 . 